\title{
A New Integrative Model to Train the Next Generation of Biomedical Scientists
}

\author{
M Dahmani Fathallah* \\ Department of Life Sciences, Arabian Gulf University, Bahrain
}

Submission: August 21, 2017; Published: October 24, 2017

*Corresponding author: M Dahmani Fathallah, Department of Life Sciences, Medical Biotechnology Program \& Office of the Dean, College of Graduate Studies, Arabian Gulf University, Manama, Bahrain, Email: d.fathallah@agu.edu.bh

\begin{abstract}
The biomedical field is undergoing profound mutations as neoteric paradigms are irreversibly making their way through and reshaping the entire healthcare landscape. As a consequence there is an urgent need to align the education and training of the next generation of biomedical scientists with the untraded technological capabilities and dewy scientific advances. Unleashing the potential of the knowledge accumulated in biomedical sciences to meet the sizable expectations for improved healthcare and quality of life, is the challenge that the next generation of biomedical scientists ought to take. In this paper, we describe a novel incrementally innovative model we have designed for the education and training of the next generation of biomedical scientists. This integrated model is partly inspired by the setting of modern clinical medical training. It calls for the creation of a physical infrastructure such as schools dedicated to biomedical sciences where education is based on the concept of learning by doing. In this model emphasis is also on linking education to real time transfer of technology, innovation and products development. Furthermore, we discuss the economics that might support this model thrive.
\end{abstract}

\section{Opinion}

The biomedical filed is witnessing profound paradigm shift and the medical practice is moving toward a personalized type of healthcare based on scientific evidences and sophisticated technologies [1]. However and for multiple reasons this move is rather slow. Among these reasons is probably the current education medical system which is still focused on the quality of the clinical training and the integration of the latest biomedical sciences in the curriculum of healthcare professional is not optimal. Consequently, there is a concerning scarcity of individuals who are appropriately trained with skills that go across biomedical sciences and clinical practices, the latter being the essential links in the 21 century healthcare chain. Currently, biomedical sciences education is scattered between various high education institutions mainly medical schools and pharmacy colleges along with life sciences colleges offering «blue sky» basic sciences (Molecular Biology, Genetic, Microbiology, Bioinformatics etc) training. Hence, nearly all of today's biomedical scientists are graduates from such unconnected institutions. As a consequence, most of them are neither adequately qualified nor fully aware about the connections between bio sciences and its medical applications, a result of their lack of appropriate training on what it takes to translate biomedical sciences into health care practices. Therefore, the health care industry has difficulties in reaping the benefits of the investments in university-based research. Nevertheless, medical education is not the only field struggling for readjustment as the entire academic world and particularly higher education, is facing a number of serious challenges as highlighted in the interesting report released in 2013 by the United Kingdom institute for public policy research and entitled '»An avalanche is coming» [2]. Indeed, student demographics are on the rise, education technologies are growing at an unprecedented pace and knowledge accumulation is spurring innovation like never before [3]. Globalization is also making its way in the academic sphere and universities are compelled to adapt to new economic environments. The need to rethink education models is high on the agenda of all higher education institutions. This is particularly true for institutions dedicated to train the next generation of life sciences and health biotechnology professionals. Indeed, the latest scientific developments have rendered the health biotechnology industry to be a sophisticated and increasingly powerful industry. This would not have happened without the necessary educational and research efforts led by the academic world. Therefore, a minted care should be taken in preparing the future generation of bio medical scientist if we want to stand a chance to meet the growing and high expectations for improved healthcare and quality of life, as the public is progressively 
aware of the potential applications of the latest developments in bio medical sciences and biotechnologies. A healthcare commensurate with the current knowledge and technical capabilities is an important issue all over today's globalized world. In addition, among the objectives of any new model that could be developed to prepare the next breed of professional bio medical scientists, is training students to understand how entrepreneurial skills can be applied in both the academic and the corporate setting. Such training should emphasize how scientific innovations can be effectively translated into business opportunities thereby addressing the educational needs and economic realities of the country and achieving a knowledgebased economy [4,5].

Taking into consideration all gaps that need to be filled and the challenges facing the education of a bio medical sciences highly skilled work force, we designed a novel educational model that can be delivered through the setting within academic institutions of schools (SBS) or institutes (IBS) dedicated to biomedical sciences which and over scientific and vocational university degrees fitted to the competitive job market of a fast-moving world. Meanwhile, such model will help project universities toward innovative twenty-first century higher education institutions.

\section{Model Description}

This novel academic model is in part inspired by the medical education concept that relies on teaching hospitals where students develop their skills and learn from practitioners in real life medical care. It consists in integrating the academic education into the links of the modern healthcare chain, namely the research and development, the clinical trials and regulatory affairs, the transfer of technology and the industrial production. This model should be delivered through a single institutional setting such as a school or institute dedicated to bio medical sciences. This is an incrementally innovative academic institutional concept based on tailoring the education to be not only based on research and development, but also to be tightly coupled to real-time industrial applications, all in one integrated geographical space. Such Institution will foster and advance the concept of learning by doing. It will realize the "from bench to bedside" or the "from molecule to man" paradigm. Consequently, the model requires a strong link with the pharmaceutical and medical industry. The involvement of these stakeholders is of paramount importance [6] as substantial part of the institution activities should be based on real medical and/or pharmaceutical projects. These projects can vary from product or service development to clinical trials or any kinds of advisory activities ranging from technical and scientific consultations to management, regulatory or legal supports. To put emphasis on these activities, graduation will be linked to the completion of such transversal industry-academia collaborative projects or the achievements of milestones of these projects, in line of the academic requirements for awarding the degrees.
Meanwhile, outside of the external collaboration, graduation will also be linked to discovery, product/service development, entrepreneurship and transfer of technology.Therefore, this institutional model is built over four overlapping layers (Figure 1). Academic education, Research and development, Industry and Transfer of technology

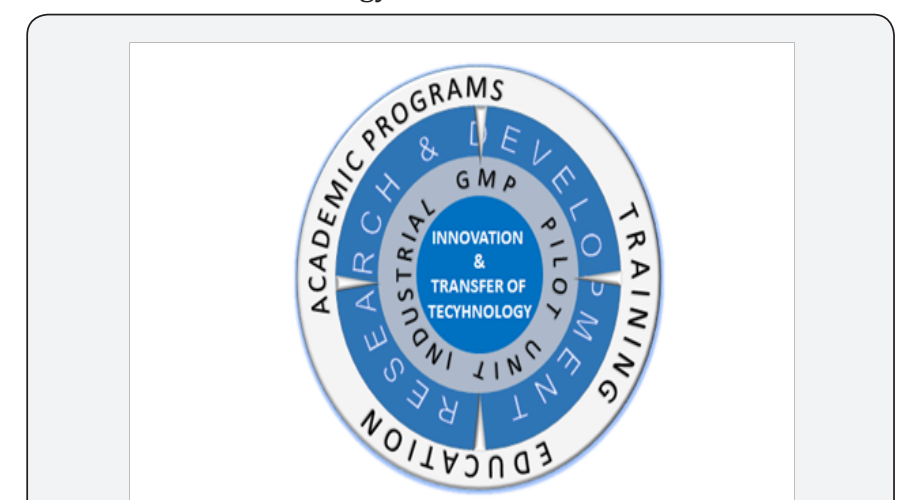

Figure 1: The four layers integrated model to train the next generation of biomedical scientists.

\section{The academic layer}

Table 1: The academic degrees to be awarded with examples of graduate programs needed to train the next generation of biomedical professionals

\begin{tabular}{|c|c|}
\hline Awarded Degree & Topics \& Programs Tracks \\
\hline \multirow{3}{*}{$\begin{array}{l}\text { Master } / \mathrm{PhD} \\
\text { in bio medical } \\
\text { sciences }\end{array}$} & $\begin{array}{l}\text { Intergrated biology (synthetic biology, system } \\
\text { biology, pharmacogenomics) }\end{array}$ \\
\hline & Gene editing \& gene therapy \\
\hline & $\begin{array}{c}\text { Computational biology \& bio drug design and } \\
\text { development }\end{array}$ \\
\hline \multirow{2}{*}{$\begin{array}{l}\text { Master in bio } \\
\text { medical sciences }\end{array}$} & $\begin{array}{c}\text { Preclinical assays, clinical trials and } \\
\text { pharmacovigilance }\end{array}$ \\
\hline & Nano biotechnology \& new drug delivery system \\
\hline \multirow{3}{*}{$\begin{array}{l}\text { Bio medical } \\
\text { sciences engineer }\end{array}$} & $\begin{array}{c}\text { Biopharmaceutical manufacturing: (bioprocess } \\
\text { engineering, CGMP manufacturing) }\end{array}$ \\
\hline & $\begin{array}{l}\text { New medical devices (new materials and } \\
\text { healthcare applications) }\end{array}$ \\
\hline & $\begin{array}{l}\text { Cellular therapy ( stem cells \& therapeutic } \\
\text { genetically modified cells production) }\end{array}$ \\
\hline \multirow{2}{*}{$\begin{array}{l}\text { Master in Bio } \\
\text { Medical Business } \\
\text { management }\end{array}$} & Bio medical economics, policies \& regulations \\
\hline & $\begin{array}{c}\text { Bio medical innovation, leadership \& transfer of } \\
\text { technology }\end{array}$ \\
\hline
\end{tabular}

The schools or institutes will deliver undergraduate and graduate education and training in biomedical sciences exclusively. Therefore, each institution will develop curricula to deliver a Bachelor degree (BBS) and a number of Masters (MBS) with various specializations in Biomedical Sciences. It will develop a Master in Biomedical Business Management (MBBM) as well as $\mathrm{PhD}$ degrees in biomedical sciences and a degree in Biomedical Engineering (Table 1).

It is of paramount importance that academic staff, instructors, mentors and managers should be carefully selected to include a 
mix of scholars, engineers, technicians that are well versed into the innovative aspect of biomedical sciences. It is recommended that all staff have a good track record of achievements or experience in the different links of the modern healthcare chain along with a passion to transmit knowledge and expertise while being capable of driving young scientists into a modern, effective and powerful learning experience. The development of the curricula should take into account that the next generation of biomedical sciences professional will be operating in a globalized society. Therefore, emphasis should be put on critical thinking, creativity, flexibility and innovation as essential personal skills that graduates need to master. In addition, graduates from Bio Medical sciences schools /Institutes need to be highly skilled in identifying the connections between biosciences and its medical applications or commercial potential. Therefore, curricula should be enhanced with business-oriented professional skills and entrepreneurial spirit training which are the best assets for students to succeed in the future workplace.

Teaching and training should be based on biotechnology education best practices [7] which include modern pedagogies, the latest education technology tools and strategies that provide robust education environment. To achieve deeper learning and understanding, students should be pushed to reach out to one another, adopt a solving problems minds, built collaborative skills while sharing knowledge and information. To succeed in these tasks, cutting edge game changer technology such as artificial intelligence [8] can be used in the class room to provide endless possibilities from creating customized content to facilitating advanced tutoring through to instructional design.

\section{The research and development layer}

In this educational model research and development (R\&D) will play multiple roles. In one hand it will be the backbone of graduate education and research training and in the other hand it will be a major link between the institution and the bio medical field stakeholders, mainly the pharmaceutical and health care industries. Indeed, the institutions' laboratories would operate like contract research organizations (CRO) where the private partner orders and sponsor the research to benefit from the institution research staff expertise. Meanwhile, graduate students will acquire research and technical knowhow or sharpen their research skills while contributing to the performance of state of the art applied research contracted by the industrial partners, therefore getting the best insights on how biomedical sciences can be linked with clinical applications. The pharmaceutical industry as well as the other biomedical care institutions will be eager to outsource their $R \& D$ activities when biomedical institutions offers them the possibility to benefit from a variety of highly skilled professional biomedical experts they otherwise cannot hire on a permanent basis. The research and development layer in our model of biomedical sciences institutions have the advantage of offering as added values a variety of high research skills in all the links of the healthcare chain in a single geographic space and under the same management. Even though the R\&D layer in our models essentially dedicated to this presumably "inspired research" it leaves room to an "in house R\&D". This activity consists in a balanced mix for new knowledge and know-how production and the mastering and application of extramural knowledge and technical know-how (Figure 2). Importantly, the topics of this R\&D need to be aligned with the health issues facing the region where the institution is located. This type of project should be managed the same way than research contracted with the industry. By doing so, this new type of academic bio medical sciences research institution will be able to provide solution to its community and therefore fulfills its social responsibility [9]. In addition, it will produce intellectual property assets that can be traded for financial benefits. This is one of the additional roles the R\&D layer can play.

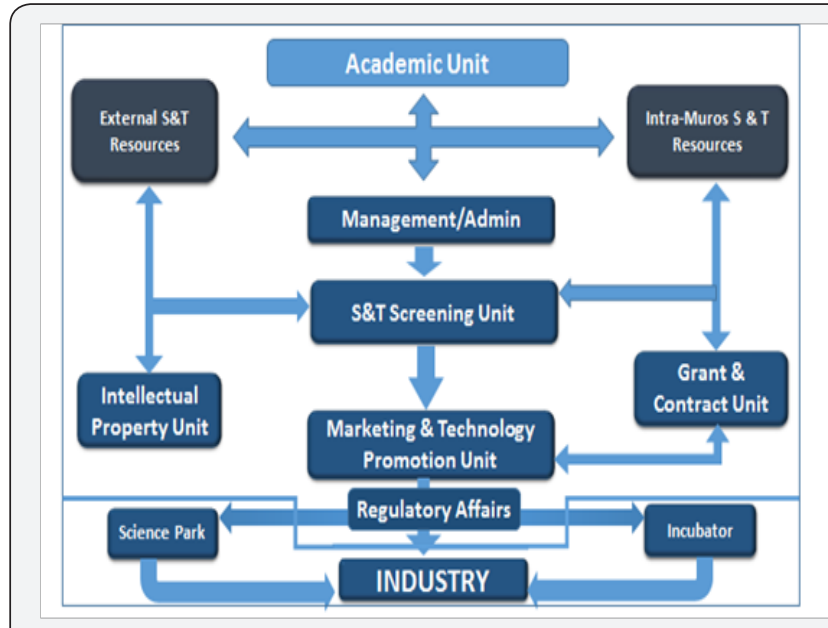

Figure 2: TTO structure for a biomedical educational institution: Each unit is designed to carry out specific tasks.

Internally generated new sciences and technologies (S\&T) as well as external S\&T are thoroughly reviewed by the screening unit for their applications potential. Selected projects are transmitted to the intellectual property unit which defines the appropriate type of IP to protect the asset. Meanwhile, the Marketing \&Technology Commercialization unit develops the strategic partnership with the industry. The grant and contract unit manages all the institution's projects and handle the legal aspects of all licensing operations in coordination with the regulator affairs unit. When the institution decides to spin off a project, it may be incubated within the institution at the startup phase or in an external incubator. Science parks are also potential partners in specific projects. The TTO Academic unit is in charge of setting and managing the curriculum of the Master degree in Biomedical Sciences Management.

\section{The industrial layer}

In this layer, the model addresses the industrial link of the healthcare chain. However, we need to distinguish the full-fledged biomedical industry from the pilot scale industrial application at the academic level. Indeed, by analogy with the clinical teaching hospitals, the model calls for establishing within the biomedical sciences school/institute, of a Good Manufacturing Practices (GMP) compliant pilot 
scale industrial facility where the students will develop their biomedical manufacturing skills. This facility can be designed to carry out state-of-the-art production technologies such as microorganism fermentation and cell culture technologies used in the manufacturing of the biological drugs or biologics, new generation of vaccines as well as cell-basedtherapeutics. Such facility involve advanced bioengineering process skilled staff and require costly equipment's for both the upstream and downstream manufacturing steps. Pilot manufacturing [10] is an important step toward the industrial scale production of all types of products used for therapeutic and /or diagnostic purposes as well as the production of experimental drugs lots used in clinical trials [11]. This layer is central to this new biomedical education model as it fulfills the concept of learning by doing. Indeed, for their mandatory rotations in the different departments of the school/institute, the undergraduate students will be required to spend an internship in this pilot plant in order to graduate. Meanwhile, the graduate students involved in the R\&D projects contracted with the industries will carry out their work under the supervision of biomedical professional experts to gain accountability and guidance. Moreover, owning and running a successful bio manufacturing pilot plant will give a competitive advantage to the biomedical School/Institute. Indeed, in addition to producing highly skilled professionals, ready for the market place, it will facilitate and spur the collaboration with the industrial sector. In addition, the knowledge generated within the institution can be more easily translated into application (products or services) and can be licensed out at a later stage for better financial returns.

\section{The transfer of technology layer}

The transfer of technology is an essential link of the healthcare chain, without it discoveries or new know-how cannot be developed into a tangible product/service that might reach the end user. Therefore, it is consistent to include this activity in this new biomedical sciences education model. The next generation of biomedical professionals needs to master all the aspects of technology transfer as these aspects should often be considered at the early stage of the R\&D phase. Moreover, technology transfer is a complex process that combines several skills which engage researchers in promoting their discoveries, and encouraging potential industrial partners to use the technology $[12,13]$. Technology transfer uses proactive approaches and requires high level of organization. Our model calls for the embodiment of a technology transfer office (TTO) within the organizational chart of the institution. The TTO shall be in charge of the promotion, commercialization, regulatory and legal (intellectual property) aspects of the technology transfer process. It will carry out real time Inside out' (Licensing out) and outside in' (Licensing in) projects while training undergraduates students on the processes during their mandatory rotations in the TTO. Besides, the TTO is central to this model and as such, involving it in the setting and execution of the strategic objectives of the institution, is imperative. In addition, the TTO will also be in charge of setting and delivering the Master in Biomedical Sciences Management (Table 1). Figure 2 depicts an example of organizational chart of a typical TTO to be set within novel biomedical sciences educational institutions.

\section{The Model's Economics}

With the emergence of new and highly sophisticated technologies and the increase of social demand for both better healthcare and education, costs in these two fields are skyrocketing all over the world. As a consequence, education and healthcare institutions struggle to provide the best products and services while controlling costs. Therefore, financial sustainability [14] is a major issue in both fields and the issue becomes crucial when it comes to institution that are at the cross road of education and healthcare, which is the case of the biomedical institutions the current model calls for. Despite the fact the economics of such model could be complicated and not easy to achieve as several factors may influence the funding and financial sustainability of the type of biomedical institutions we describe in this paper. Below we present the outline of a business model that might help achieve financial sustainability and could be applied to a not-for-profit as well as a for profit biomedical institution adopting our model. It will use a variety of sources to sustain the various activities with revenues stream that can be based on the following:

- $\quad$ Student's tuition fees.

- Professional training.

- $\quad$ Alliances and contracts with the industry.

- $\quad$ Service contracts.

- IP and early licensing in /development stages/ and licensing out.

- $\quad$ Public grants.

- Endowments.

In addition the setting of the biomedical institutions as described in our model can be capital intensive and creative investment strategies and capitalization on existing assets will be needed.

Industry partners can also reduce the costs incurred during the research and development stage by partnering with a biomedical institution such the one we describe in our model and/or licensing technology from it.

\section{Conclusion}

The future of biomedical sciences will be as good as the human resources that will care about this sector and the quality of the education these resources will take could make the difference. The model described in this paper is an incrementally innovative educational model crafted for the biomedical sciences field. It will close the theory and practice gap while enhancing the training of the next generation of biomedical sciences. It 
aligns the educational needs with the increasing complexity of the field. In addition to integrating all the links of the healthcare chain in the same geographical space and keep it strongly linked to the professional and the socio-economic environments. As a spill over, this model will lead to the development of private enterprises in the local and regional economy. Finally, such biomedical school/institute model will help the mother university getting recognition and increasing its reputation as an innovative twenty-first century university [15].

\section{References}

1. Fathallah MD (2017) Genomics, gene editing and biologics: The bolsters of the new medical paradigm. Current Trends in Biomedical Engineering and Biosciences 6(4).

2. Barber M, Donelly K, Rizi S (2013) An avalanche is coming, Higher and the revolution ahead. London IPPR, UK.

3. Barber M, Donelly K, Rizi S (2012) Oceans of innovation, the altlantic, the pacific, Global leadership and the future of education. London IPPR, UK.

4. Kunert KJ, Okole B, Vorster BJ (2012) A general model for training the next generation of biotechnology entrepreneurs based on recent experience of USA-UK-South Africa collaborations. Journal of Commercial Biotechnology 18(3): 63-66.

5. Wong PK, Ho YP, Singh A (2007) Towards and "Entrepreneurial University" model to support knowledge-based economic development: The case of the National University of Singapore. World Development 35(6): 941-958.

This work is licensed under Creative

Commons Attribution 4.0 Licens

DOI: 10.19080/AIBM.2017.07.555702
6. Barton D (2012) Young, gifted and slack: the skill gap must be bridged if the world is to avoid dire consequences. The Economist.

7. Kjelstrom JA, Jamison McClung D, Friedman Y (2008) UC Davis biotechnology program. Best practices in biotechnology education. Washington DC: Logos, Press, USA, pp. 85-111.

8. Leopold T (2017) A professor built an AI teaching assistant for his courses-and it could shape the future of education. Business Insider.

9. Devol R, Shen IL, Bedroussian A, Zhang N (2013) A matter of degrees: The effect of educational attainment on regional economic prosperity, Milken Institute, Santa Monica, California, USA.

10. Riscaldati E, Ciabini A, Baccante A, Moscatelli D, Errichetti MF, et al. (2006) Set up and optimization of a fermentation protocol for the production of a human antibody fragment (Fab') express in E. coli. Prepilot and cGMP pilot scale studies. Microbial Cell Factories 5(Suppl 1): 29.

11. Jacoby R, Pernenkil L, Harutunian S, Heim M, Sabad A, et al. (2015) Advanced Biopharmaceutical Manufacturing: An Evolution Under way Deloitte Consulting LLP, USA.

12. Fathallah MD (2009) Mechanistic of technology transfers, in 'technology transfer in the pharmaceutical and medical fields'. King Abdul Aziz Press, Ryadh, KSA.

13. Buchanan J, Wordsworth S, Schuh A, Friedman Y (2013) Issues surrounding the health economic Best practices in Biotechnology education. Washington DC, Logos, Press, USA, p. 342.

14. Dennen J, Drettler T (2012) The financially sustainable university. Bain brief.

15. Christensen CM, Eyring HJ (2011) The innovative university, Jossey Bass, San Francisco, California, USA.

\section{Your next submission with Juniper Publishers will reach you the below assets}

- Quality Editorial service

- Swift Peer Review

- Reprints availability

- E-prints Service

- Manuscript Podcast for convenient understanding

- Global attainment for your research

- Manuscript accessibility in different formats

( Pdf, E-pub, Full Text, Audio)

- Unceasing customer service

Track the below URL for one-step submission https://juniperpublishers.com/online-submission.php 